\title{
Ecotourism, Stated Preferences, a Paradox between Environmental Awareness and Environmental Actions: The Case of Monteverde, Costa Rica
}

\author{
Irene Alvarado-Van der Laat \\ EARTH University, Guácimo, Costa Rica \\ Email: ialvarad@earth.ac.cr
}

Received 6 November 2015; accepted 15 December 2015; published 18 December 2015

Copyright (C) 2015 by author and Scientific Research Publishing Inc.

This work is licensed under the Creative Commons Attribution International License (CC BY). http://creativecommons.org/licenses/by/4.0/

\section{(c) (i) Open Access}

\begin{abstract}
This study aims to assess the relation between the so called "Ecotourism" behavior and Willingness-To-Pay (WTP) in order to compensate on site for their carbon foot print, plus their familiarity with common environmental terms, in the Monteverde Region of Costa Rica. A Contingent Valuation Method (CVM) was decided upon as the best way to determine the willingness to pay (WTP). While the scope of this study is limited by the low season for tourism, the study finds a paradox between the behaviors of the self-called ecotourist suggesting that the term is more related to the location of the area visited, rather than any attempt by the tourist to alter their travel behavior. That could have a negative impact on the very wildlife where the park is trying to protect.
\end{abstract}

\section{Keywords}

National Parks, Ecotourism, Environmental Awareness, Willingness-to-Pay, Stated Preference

\section{Introduction}

Ecotourism has been addressed as a developing country’s best stake to environmental preservation and economic accomplishments. At the origin of its practice in 1980, the concept of ecotourism flourished, meaning "traveling to relatively undisturbed or uncontaminated natural areas with the specific objectives of studying, admiring, and enjoying the scenery and its wild plants and animals, as well as any existing cultural manifestations (both past and present) found in these areas” [1].

The International Ecotourism Society establishes the term ecotourism "described with the following five cri- 
teria: nature conservation, low impact, sustainability, meaningful community involvement and environmental education". The success of ecotourism depends on the correct execution of these criteria. Every country gives emphasis to make tourism as environmentally friendly by upholding nature conservation with low negative impact on the location [2].

Research on nature tourism have shown that up to $50 \%$ of the total travel marketplace will like to visit a natural area during a voyage, including a national park if possible [3]. Most of the main ecotourism destinations have reported notable increases in visits to protected areas. Ecotourists have always been attracted to national parks and protected areas, while simply visiting a park or natural area is nature tourism not ecotourism, visitor trends to parks give an indication of growth of ecotourism as well [4].

Over the years, Costa Rica has become the "poster child" for ecotourism which thanks to its climate, beaches, rainforests, exotic flagship species, volcanoes, hiking, fishing, and surfing destinations [5].

In the 1980s, the Monteverde region in the Northwestern part of Costa Rica became an established tourism destination. This time frame corresponds with the rise of ecotourism. Located near the top of the Tilarán Mountain Range are the "Monteverde Cloud Forest Reserve", the "Santa Elena Reserve" and the Children Eternal Forest. All three parks sit on the Continental Divide with an altitude of between 600 to $1842 \mathrm{~m}$. This altitude contains the highest diversity of flora and fauna, providing a unique situation, helping to support a complex and far-reaching ecosystem such as the Tropical Montane Cloud Forest which makes it a prime destination for environmentally minded travelers, also called ecotourists, to one of the world's most complex ecosystems [6].

Costa Rica is attempting to achieving net neutrality by the year 2021, by reducing 5.8 million tons of CO2 emissions. Tourism is one of the main industries in Costa Rica; the ability to reach this goal has been augmented by the economic value, the local and international community place on this resource [7].

Economic valuation can be defined as the "attempt to assign quantitative values to the goods and services provided by environment resources, whether or not market prices are available" [8]. The environmental resources struggle with the problem of limited information regarding price, costs, and quantity consumed. For these reasons, the benefits and costs of these resources are difficult to determine. The problem can be solved by using the economic valuation process in finding wiliness to pay (WTP) value [9].

Non-market values can be categorized as use values and non-use values. The use value of an asset is the value to society from the active use of the asset. This value involves direct and indirect use value. Non-use values reflect the value that an individual or society places on an asset, even if they never intend to use this asset directly. This involves existent values such as biodiversity and habitat, and bequest values protecting the environment for the future generations [10].

Nuva and Mad [11] suggested that environmental valuation was based on the assumption that individuals were willing to pay for environmental achievements and on the other hand, were willing to accept compensation for some environmental losses. The individual demonstrates preferences which, in turn, place values on environmental resources.

Brouwer, Brander and Van Berkering [12] found that significant differences were found between travelers from Europe, North America, Asia and the rest of the world. They sustain that Europeans are most aware and willing to pay for carbon offsets when accounting for the distances flown and associated greenhouse emission during their flights, whereas the North Americans and Asians are less informed and less willing to act, even when not accounting for income differences.

Contingent valuation (CVM) is a method of estimating the value that a person places on goods which have been commonly used in environmental analysis that together with a stated preference approach allow to estimate the monetary value of non-marketed goods [13].

A questionnaire is used to ask people what they are willing to pay for benefits or willing to receive for tolerating a cost [14]. This study aims to assess the relation between the so called "Ecotourism" behavior and Willingness-To-Pay (WTP) in order to compensate on site for their carbon foot print, plus their familiarity with common environmental terms and any other actions that they are willing to take in relation to their environmental awareness.

\section{Methods}

The study was done in Monteverde, Costa Rica, in April 2014. The surveys were conducted at the entrances of the 
two main parks, Monteverde Private Reserve and Santa Elena National Park. Participation in each survey was voluntary, anonymous and in Spanish or English. To begin with each person was asked a discriminatory question of whether or not they considered themselves eco tourists.

The survey was divided into three sections. Section number one inquired about demographic information including age, sex, level of education and occupation. The second section of the survey asked about the types of transportation used to arrive to the region and the third part of the survey used multi-choice questions in order to analyze the individual's opinions and knowledge of environmental programs. Question number six inquired about the most willing to do: a) action to compensate or b) change in behavior (mitigate) for their travel related emission.

To analyze the data two types of statistical methodologies where used in order to determine if a distribution of observed frequencies differs from the theoretical expected frequencies the chi-square technique. Chi-square statistics allow the evaluation of categorical data, instead of using means and variances, this test uses frequencies. The value of the chi-square statistic is given by the following Formula (1):

$$
X^{2}=\operatorname{Sigma}\left[(O-E)^{2} / E\right]
$$

where:

$X^{2}$ is the chi-square statistic,

$O$ is the observed frequency and

$E$ is the expected frequency.

\section{Assessing the willingness to compensate or willingness to mitigate of the ecotourism}

To evaluate the stated preferences from a hypothetical question regarding willingness to pay or compensate (WTP) or the willingness to mitigate (WTM) for non-market goods, a Contingent Valuation Methods was used. The questioner asked four questions related to change in behavior (mitigation-actions) and four questions related to compensation (willingness to pay), which is expressed in Formula (2).

$$
\begin{aligned}
Y^{*}= & \beta 0+\beta 1(\mathrm{GEN})+\beta 2(\mathrm{ACF})+\beta 3(\mathrm{COMPK})+\beta 4(\mathrm{MITGK})+\beta 5(\mathrm{COFP}) \\
& +\beta 6(\mathrm{ACT}-\mathrm{CAR})+\beta 7(\mathrm{ACT}-\mathrm{TB})+\beta 8(\mathrm{NACT}-\mathrm{PRECY})+\beta 9(\mathrm{NACT}-\mathrm{PIWMG}) \\
& +\beta 10(\mathrm{NA}-\mathrm{PCN})+\beta 11(\mathrm{ACT}-\mathrm{VCT})+\beta 12(\mathrm{ACT}-\mathrm{VPT})+\beta 13(\mathrm{NACT}-\mathrm{PCT}) \varepsilon
\end{aligned}
$$

\section{General:}

$Y^{*}=$ WTP of the respondent

$\beta 0$ to $\beta 13=$ Regression coefficients

GEN = Gender ( $1=$ male; 0 = otherwise $)$

$\varepsilon=$ Disturbance term

\section{Awareness and knowledge:}

ACF $=$ aware of carbon foot print associated with travel

COMPK = familiar with the term compensation

MITGK = familiar with the term mitigation

COFP = aware of carbon offset programs

\section{Mitigation:}

ACT-CAR = mitigation, carpooling

ACT-TB = mitigation, travel by bus

ACT-VCT = mitigation, volunteering clean up trash

ACT-VPT = mitigation, volunteering planting trees

\section{Compensation:}

NACT-PRECY = compensation, pay to institute recycling

NACT-PIWMG = compensation, pay for improved waste management

NA-PCN = compensation, pay for carbon neutral vehicle/taxi

NACT-PCT = compensation, paying a carbon tax to offset emissions

To derive mean willingness-to-pay quantities from the binary data, a multiple regression analysis was employed in testing the internal validity of the contingent valuation method, the highest amount of the respondents were willing to pay was assumed to equal the highest of the willing to do, used in the study. 


\section{Limitation of the Study}

The interviews were carried out during the low season of the tourism activity. Each visitor was asked if they considered themselves as eco tourists. INFOSTA statistical software was used to analyze the data.

\section{Results}

The result of this study was divided into sections: section A, covered demographic information; section B inquired about the willingness to pay to compensate the emissions in relation with demographic information of the self-called "ecotourist", using Chi-square statistical methodology to allow the evaluation of categorical information with frequencies. Section $\mathrm{C}$ inquired the relation within the environmental awareness of the tourist visiting the Monteverde region and the willingness to pay to compensate their carbon emissions.

Finally section D, evaluated the stated preferences regarding willingness to pay (WTO) for non-markets goods, using the Contingent Valuation Methods.

\subsection{Demographic Information}

A total of 100 surveys were done at the entry of the main visitors Parks in Monteverde and 90 of the surveys survey's where accepted as complete. The demographic evaluated parameters of age groups, education and gender where well represented in each category (Table 1). However college degrees and post college degrees represents the vast majority (94\%) of the visitors.

The average income range expressed by the visitors presented the challenge of cultural differences; foreigners expressed income as yearly income and Costa Ricans expressed their income on a monthly basis. To be able to evaluate using a similar social income categories four percentiles where created that represent this structure (Table 2) 30\% of the visitor are from the percentile A, 31\% where from the percentile D, 26\% where from the percentile C, and only $12 \%$ where from the percentile B (Table 2).

Table 1. Demographic information of tourists visiting the parks in the Monteverde Region, Costa Rica, 2014.

\begin{tabular}{|c|c|c|c|c|c|c|c|c|c|c|c|c|c|c|}
\hline \multicolumn{15}{|c|}{ Statistics: Demographics in relation to willingness to pay } \\
\hline & \multicolumn{4}{|c|}{ Gender } & \multicolumn{5}{|c|}{ Education } & \multicolumn{5}{|c|}{ Age } \\
\hline tot & $\mathrm{m}$ & $\mathrm{f}$ & $\% \mathrm{~m}$ & $\% \mathrm{f}$ & $<\mathrm{HS}$ & High School & College & College+ & DNS & $<18$ & $18-25$ & $26-40$ & $41-60$ & $60+$ \\
\hline 29 & 16 & 13 & 55.17241 & 44.82759 & 0 & 0 & 9 & 19 & 1 & 0 & 7 & 15 & 7 & 3 \\
\hline 23 & 9 & 14 & 39.13043 & 60.86957 & 0 & 1 & 9 & 14 & 0 & 0 & 4 & 13 & 3 & 1 \\
\hline 11 & 4 & 7 & 36.36364 & 63.63636 & 0 & 1 & 4 & 6 & 0 & 0 & 2 & 6 & 3 & 0 \\
\hline 12 & 4 & 8 & 33.33333 & 66.66667 & 0 & 1 & 2 & 9 & 0 & 0 & 1 & 5 & 4 & 2 \\
\hline 6 & 2 & 4 & 33.33333 & 66.66667 & 0 & 2 & 1 & 3 & 0 & 0 & 1 & 1 & 3 & 0 \\
\hline 6 & 4 & 2 & 66.66667 & 33.33333 & 0 & 0 & 1 & 5 & 0 & 0 & 0 & 2 & 3 & 1 \\
\hline 3 & 2 & 1 & 66.66667 & 33.33333 & 0 & 0 & 1 & 2 & 0 & 0 & 0 & 2 & 1 & 0 \\
\hline 90 & 41 & 49 & & & & 5 & 27 & 58 & 1 & 0 & 15 & 44 & 24 & 7 \\
\hline
\end{tabular}

Table 2. Demographic information in relation to income from tourists visiting the parks in the Monteverde Region, Costa Rica, 2014.

\begin{tabular}{|c|c|c|c|}
\hline \multicolumn{4}{|c|}{ Explanation of salary groups } \\
\hline \multicolumn{4}{|c|}{ Note that groups are based on relative salaries for Costa Ricans and foreigners, not strictly on exchange rate } \\
\hline Income percentile & Dollars & Colones & Total \\
\hline A & $<25 \mathrm{k}$ & $<250 \mathrm{k}$ & 27 \\
\hline $\mathrm{B}$ & $25 \mathrm{k}-50 \mathrm{k}$ & $250 \mathrm{k}-500 \mathrm{k}$ & 11 \\
\hline $\mathrm{C}$ & $50 \mathrm{k}-75 \mathrm{k}$ & $500 \mathrm{k}-750 \mathrm{k}$ & 24 \\
\hline $\mathrm{D}$ & $75 \mathrm{k}+$ & $750 \mathrm{k}^{+}$ & 28 \\
\hline
\end{tabular}




\subsection{Demography of the Self-Called "Ecotourist" and Willingness to Pay to Offset}

Using Chi-square statistical methods for the demographic categorical data of age, gender, education and income in relation to the dichotomous choice expressed (yes or no) of the willingness to pay to offset their travel emissions during the visit to Monteverde region were analyzed.

The analysis found no significant differences in relation to their willingness to pay and the age categories; no significant differences between gender and willing to pay, no significance difference between education and willingness to pay and no significant difference between income and willingness to pay in order to offset their carbon emission of the self-identified as an eco-tourists that visited the Monteverde Private Reserve and or the Santa Elena National Park (Figure 1). Besides these results, it is important to high light that all the categories express an average between a $90 \%$ to $65 \%$ positive attitude to pay to offset their carbon emission.

The fifth category evaluated in relation to their wiliness to pay was the country of origin.

The research categorizes the origins of the tourists visiting the two parks in four groups: a) United Stated and Canada, b) Europeans, c) Costa Rican citizen and d) citizens from other destination such Asia and Africa. However the analysis did not find any significance differences between this category and their willingness to pay (Figure 2). It is important to mention the lack of disposition expressed from tourist representing the Asia-African region (65\% not willing to pay) in relation to the other regions of the world.

\subsection{Environmental Awareness and Willingness to Pay to Offset Carbon Emissions}

Ecotourism is defined by its two main objectives conservation of nature and improved life styles for local inhabitants. Environmental education is one of the five criteria for performing ecotourism, it is relevant to determine if the ecotourist really has the level of environmental awareness in relation to their ability to pay in order to offset their carbon emission.

The results show highly significant differences in Ecotourist's responses between their willingness to pay in relations to their awareness of their carbon foot print associated with their travel (Figure 3).

The results also found significant differences in Ecotourists' responses between their willingness to pay in relations to familiarly to the term mitigation (Figure 4). The research does not show significant difference in relation with the familiarity of the term compensation.
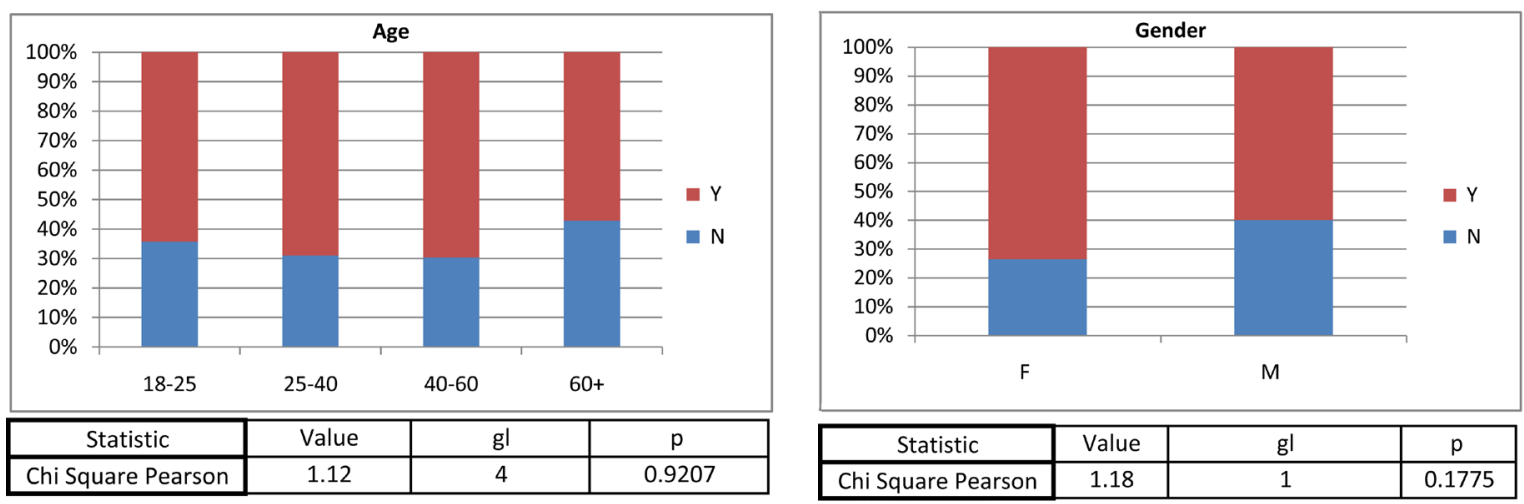

\begin{tabular}{|c|c|c|c|}
\hline Statistic & Value & gl & $\mathrm{p}$ \\
\hline Chi Square Pearson & 1.18 & 1 & 0.1775 \\
\hline
\end{tabular}
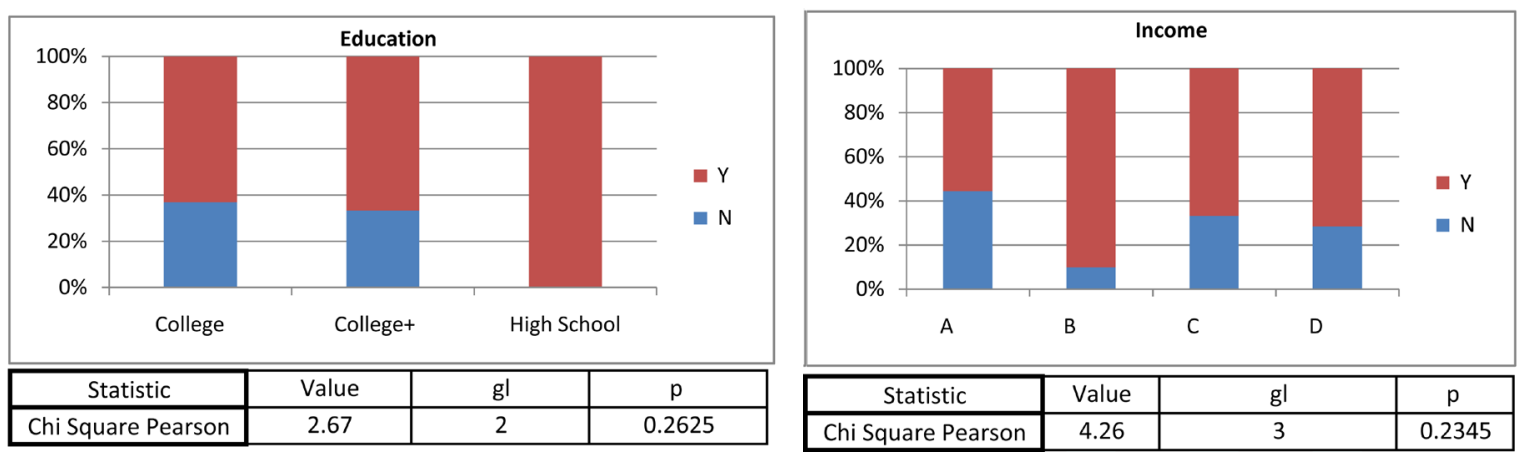

Figure 1. Demography and wiliness to pay expressed by the tourist visiting the Monteverde Region, Costa Rica, 2014. 


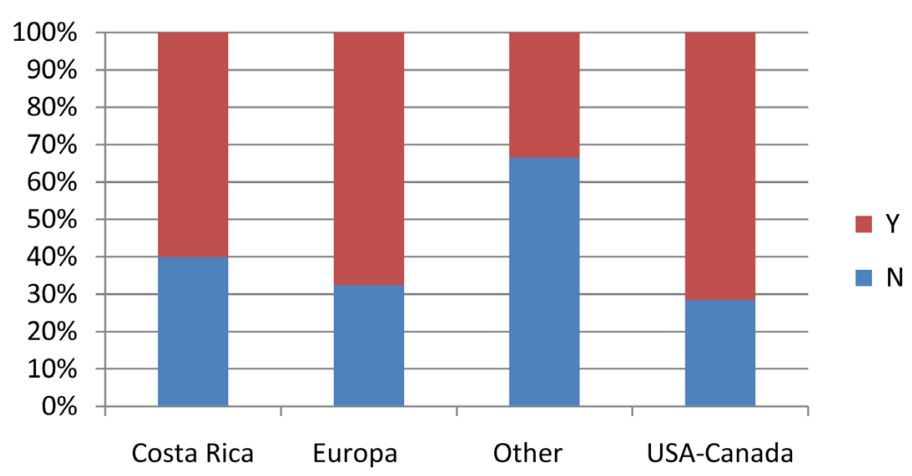

Figure 2. Word regions and wiliness to pay to offset their carbon emission expressed by the tourist visiting the Monteverde Region, Costa Rica, 2014.

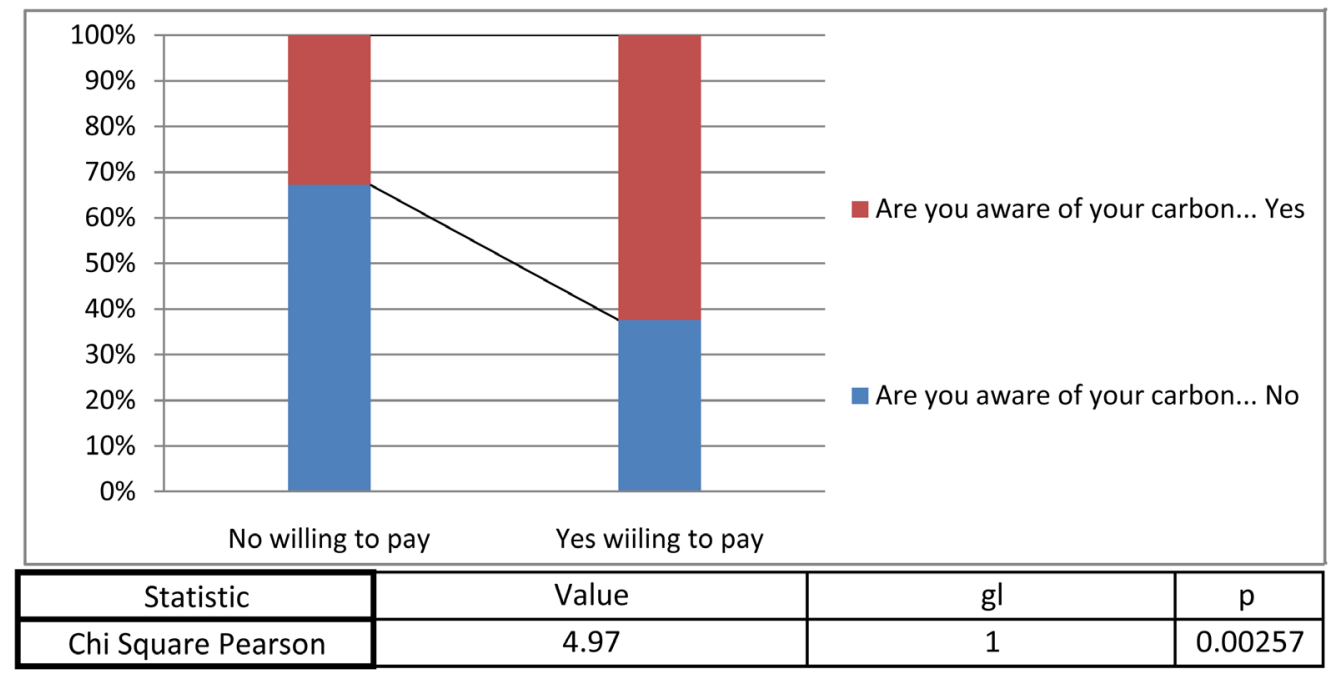

Figure 3. Willing to pay to offset vs. awareness of the carbon foot print associated with travel emissions expressed by the ecotourist. Monteverde, Costa Rica, 2014.

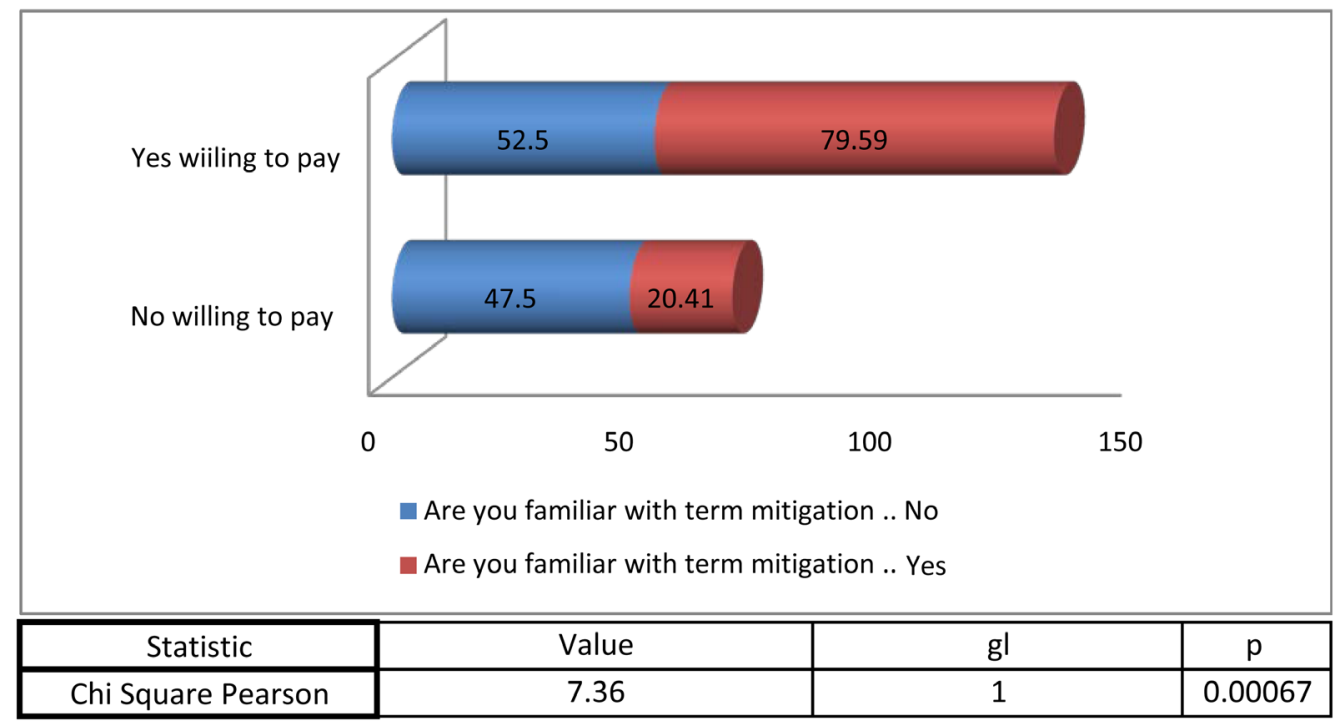

Figure 4. Willing to pay to offset vs. familiarity with the term mitigation expressed by the ecotourist. Monteverde, Costa Rica, 2014. 
Finally the results show highly significant differences in ecotourist responses between their willingness to pay in relations to their awareness to different carbon offset programs (Figure 5).

\subsection{Stated Preferences}

In order to evaluate the stated preferences, a Contingent Valuation Methods was used. Four questions related to mitigation (change in behavior) where analyzed and four questions related to compensation (willingness to pay) were also analyzed. Table 3 presents all the variable analysis used in the regression model. Results demonstrate that the less willingness to do is paying for carbon neutral vehicles or taxis.

In the extreme, the most preference expressed by the ecotourist is paying to improve waste management (Table 4).

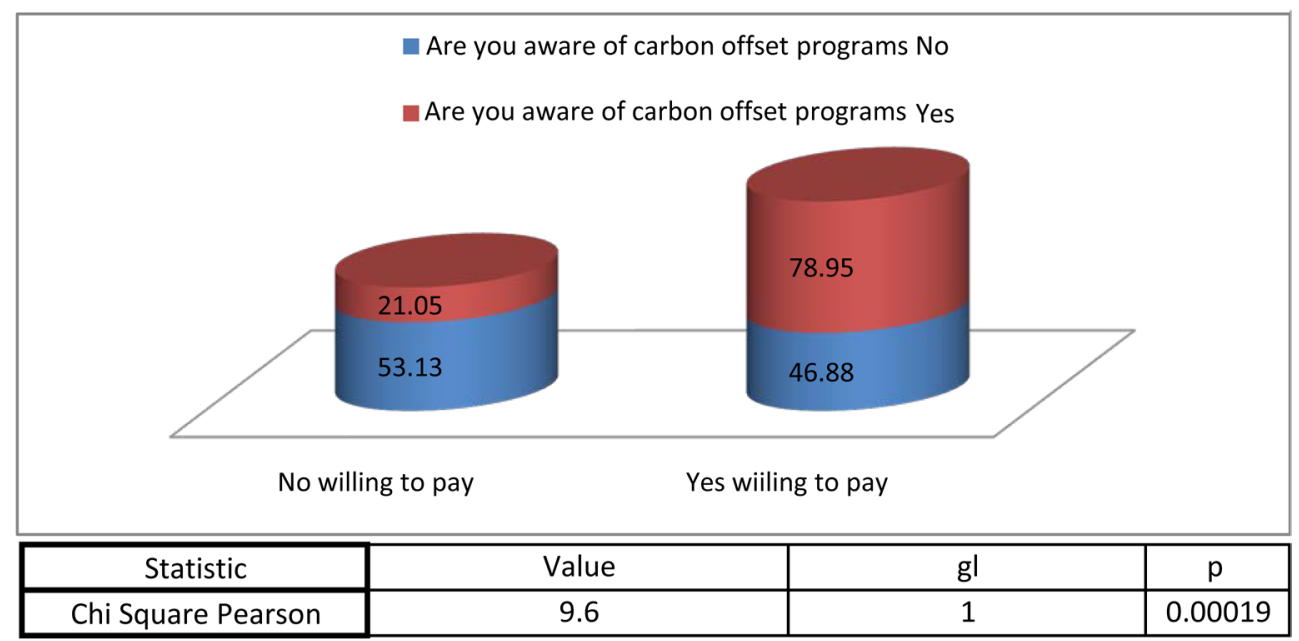

Figure 5. Willing to pay to offset vs. awareness of different carbon offset programs expressed by the ecotourist. Monteverde, Costa Rica, 2014.

Table 3. Variable analysis using the regression model of the less willing actions to do expressed from the ecotourist who visit Monteverde, Costa Rica, 2004.

\begin{tabular}{|c|c|c|c|c|c|c|c|}
\hline Parameter's & Est. & E.E. & O.R. & Wald LI (95\%) & Wald LS (95\%) & Wald Chi & $p$-valor \\
\hline Constante & -2.05 & 1.07 & 0.13 & 0.02 & 1.05 & 3.67 & 0.0554 \\
\hline Gender_M & -0.53 & 0.56 & 0.59 & 0.2 & 1.75 & 0.9 & 0.3424 \\
\hline ACF: Are you aware of the carbo & 0.91 & 0.81 & 2.5 & 0.51 & 12.15 & 1.28 & 0.2572 \\
\hline COMPK: Are you familiar with the & -0.36 & 0.78 & 0.7 & 0.15 & 3.21 & 0.21 & 0.6436 \\
\hline MITGK: Are you familiar with the & 1.07 & 0.69 & 2.9 & 0.76 & 11.16 & 2.41 & 0.1207 \\
\hline COFP: Are you aware of carbon of & 0.75 & 0.67 & 2.13 & 0.57 & 7.9 & 1.27 & 0.2603 \\
\hline ACT-CAR: a_1.00 & -0.48 & 0.57 & 0.62 & 0.2 & 1.91 & 0.7 & 0.404 \\
\hline ACT-TB: b_1.00 & 1.23 & 0.71 & 3.42 & 0.86 & 13.63 & 3.05 & 0.081 \\
\hline NACT-PRECY: c_1.00 & 0.2 & 0.71 & 1.22 & 0.3 & 4.92 & 0.08 & 0.7811 \\
\hline NACT-PIWMG: d_1.00 & 1.33 & 0.7 & 3.8 & 0.97 & 14.85 & 3.67 & 0.0553 \\
\hline NA-PCN: e_1.00 & -0.03 & 0.69 & 0.97 & 0.25 & 3.73 & $2.10 \mathrm{E}-03$ & 0.9631 \\
\hline ACT-VCT: f_1.00 & 0.16 & 0.66 & 1.17 & 0.32 & 4.24 & 0.06 & 0.8094 \\
\hline ACT-VPY: g_1.00 & 0.53 & 0.69 & 1.7 & 0.44 & 6.55 & 0.6 & 0.4388 \\
\hline NACT-PCT: h_1.00 & 0.68 & 0.67 & 1.98 & 0.53 & 7.42 & 1.03 & 0.3102 \\
\hline
\end{tabular}


Table 4. Variable analysis using the regression model of the highest most willing to do expressed from the ecotourists who visited Monteverde, Costa Rica, 2004.

\begin{tabular}{cccccccc}
\hline Parameters & Est. & E.E. & O.R. & Wald LI (95\%) & Wald LS (95\%) & Wald Chi & $p$-valor \\
\hline Constante & -0.66 & 0.42 & 0.52 & 0.23 & 1.18 & 2.47 & 0.1162 \\
COFP: offset program_Y & 1.32 & 0.51 & 3.75 & 1.38 & 10.18 & 6.72 & 0.0095 \\
NACT-PIWMG: d_1.00 & 1.56 & 0.55 & 4.76 & 1.62 & 13.95 & 8.09 & 0.0045 \\
\hline
\end{tabular}

\section{Discussion}

Costa Rica is a country of 4.7 million inhabitants whose main attractions are its natural beauties, adventure destinations and extensive biodiversity totaling $4.5 \%$ of the world total and has a well establish Eco tourism destination. In 2013 a record 2.42 million tourists visited the country, representing an increase of $3.6 \%$ compared to 2.34 million in 2012. Of them approximately 70,000 visited the Monteverde Region.

The small community of Monteverde is famous for its association with the Monteverde Cloud Forest Reserve, and is a small village located near the entrance of the cloud forest, that has been developed by local residents in order to service the large number of tourists who pass through. The dynamism of business in general is due to the natural impulse that comes from a healthy biological environment. The main attraction is the Reserve. Concerns for the Monteverde environmental problems and environmental culture are very widespread, and that social actor's precedence conservation of nature above the interests of economic tourism, commitments and collective action in relation to programs effective environmental management are still quite limited and is very limited connection with the eco-tourist.

While the scope of this study is limited by the low season for tourism, review and analysis of the results and relevant literature paints a convincing picture that the self-called ecotourism behavior could have a negative impact on the very wildlife the park is trying to protect.

When a Contingent Validation methodology is used, it is essential that all demographic parameters are statistically represented.

The data found in relation with the demographic information and the willingness to pay to offset their carbon foot print (Multi-graphic 2) was unexpected, and contradictory of the classic assumption that younger groups (18 - 25) and groups with higher education (college degree or more) would be more willing to pay for their emission, but is consistent with the findings of a study done by Matteo, P. [15] in the region of Eughabnead Hill, Italy.

The study did not find significant differences between people from different countries of origin. However the study reflected that visitors from Asia-African region have the least disposition and awareness related to environmental issues,

From this study it is possible to conclude that there is a disconnection between the self-identified ecotourist and the real principles of ecotourism. The results point out a general lack of knowledge and even confusion among eco-tourists on environmental basic concepts as mitigation and compensation.

The research suggested that the term ecotourism travel is more related to the location, rather than any attempt by the tourist to alter their travel behavior.

\section{Conclusions and Recommendations}

No significance differences were found between people from different countries of origin. It's assumed that Europeans are more environmentally sensitive and more likely to pay or implement action to mitigate their carbon foot print, but the research finds no significance difference in this regard. However, the study reflects that visitors from Asia-African region have the least disposition and awareness related to environmental issues. This is important due to the fact that in recent years, Costa Rica has been focusing on promoting the country as a tourist destination in the Asian region, especially China.

From this study, it is also possible to conclude that there is a disconnection between the self-identified ecotourist and the real principles of ecotourism. The results point out a general lack of knowledge and even confusion among ecotourists on environmental concepts as basic as mitigation and compensation. The change in behavior is a process and needs to be developed as part of integral intervention. 
Costa Rican Tourism Board and the Monteverde local government as well as private agencies should emphasis the cognitive area of environmental knowledge, to be able to develop an environmental sensibility to finally develop an environmentally responsible behavior that produce a change in travel patterns.

\section{References}

[1] Menkhaus, S. and Lober, D.J. (1996) International Ecotourism and the Valuation of Tropical Rainforests in Costa Rica. Journal of Environmental Management, 47, 1-10. http://dx.doi.org/10.1006/jema.1996.0031

[2] Bhuiyan, A. and Siwar, C. (2010) Ecotourism and Environmental Education: An Opportunity for Bangladesh. Proceedings of International Conference on Environmental Aspects of Bangladesh (ICEAB10), Japan, 4 September 2010, 43-44.

[3] Goodwin, H. and Roe, D. (2001) Tourism, Livelihoods and Protected Areas: Opportunities for Fair-Trade Tourism in and around National Parks. International Journal of Tourism Research, 3, 377. http://dx.doi.org/10.1002/jtr.350

[4] Wood, M. (2002) Ecotourism: Principles, Practices \& Policies for Sustainability, United Nations Environment Programme. United Nations Publication, France.

[5] Honey, M. (2003) Giving a Grade to Costa Rica’s Green Tourism. NACLA Report on the Americas, 36, 39-46.

[6] Koens, J., Dieperink, C. and Miranda, M. (2009) Ecotourism as a Development Strategy: Experiences from Costa Rica. Environment, Development \& Sustainability, 11, 1225. http://dx.doi.org/10.1007/s10668-009-9214-3

[7] Boddiger. D. (2002) A First Step Toward Carbon Neutrality. http://www.ticotimes.net/2012/10/19/a-first-step-toward-carbon-neutrality

[8] Barbier, E., Acreman, C. and Knowler, D. (1997) Economic Valuation of Wetlands: A Guide for Policy Makers and Planners. Ramsar Convention Bureau, Gland, Switzerland.

[9] Gómez-Baggethun, E. and de Groot, R. (2007) Capital natural y funciones de los ecosistemas: explorando las bases ecológicas de la economía. Ecosistemas, 16, 4-14. http://www.revistaecosistemas.net/articulo.asp?Id=496

[10] Kim, S., Kevin, K., Wong, F. and Cho, M. (2004) Assessing the Economic Value of a World Heritage Site and Willingness to Pay Determinants: A Case of Changdeok Palace. Journal of Tourism Management, 21, 130-148.

[11] Nuva, R., Mad, N.S. (2009) Willingness to Pay towards the Conservation of Ecotourism Resources at Gunung Gede Pangrango National Park, West Java, Indonesia. Journal of Sustainable Development Vol2, $\mathrm{N}^{\circ} 2$.

[12] Brouwer, R., Brander, L. and Van Beukering, P. (2008) “A Convenient Truth”: Air Travel Passengers’ Willingness to Pay to Offset Their CO2 Emissions. Climatic Change, 90, 299-313. http://dx.doi.org/10.1007/s10584-008-9414-0

[13] Lo, A. and Jim, C. (2010) Willingness of Residents to Pay and Motives for Conservation of Urban Green Spaces in the Compact City of Hong Kong. Urban Forestry \& Urban Greening, 9, 113-120. http://dx.doi.org/10.1016/j.ufug.2010.01.001

[14] Choong-Ki, L. and Sang-Yoel, H. (2002) Estimating the Use and Preservation Values of National Parks’ Tourism Resources Using a Contingent Valuation Method. Tourism Management, 23, 531-540.

[15] Mateo, P., Brotto, L. and Prampano, R, (2013) Willingness to Pay of Tourists for CO2 Offsetting; a Survey for the Organization of a Green Fund in the Euganean Hills Area. Master Science Course Forest and Environmental Science. Università degli studi di padova Teritorio e sistemi agro-forestali. http://tesi.cab.unipd.it/44216/1/Pramparo_Rudi.pdf 